\title{
Price Squeezes as an Exploitative Abuse
}

\author{
Discussion Paper no. 2021-05
}

\section{Zhijun Chen}

\begin{abstract}
:
Price squeezes have been commonly viewed as an exclusionary abuse under the argument of "constructive refusal to deal", however, such an argument has been challenged by the courts and legal scholars. This paper proposes an exploitative rationale for price squeezes. A vertically integrated dominant firm can exploit efficiency gains from a downstream competitor and price squeezing is a necessary condition for such exploitation. Price squeezing forces the competitor to produce at a lower marginal cost than the dominant firm so that the dominant firm can earn more than the monopoly profit by extracting part of efficiency gains from the rival. Exploitation through price squeezing reduces the rival's profit unfairly and distorts the production efficiency without benefiting consumers. Prohibiting price squeezes benefits the competitor and improves production efficiency without harming consumers. This paper lays a solid economic foundation for treating price squeeze cases and contributes to reconciling the diverging approach adopted by the courts in the United States and the European Union in recent price squeeze cases.
\end{abstract}

Keywords: Price Squeeze, Margin Squeeze, Vertical Integration

JEL Classification: D42, L42

Zhijun Chen: Monash University (email: chenzj1219@gmail.com).

(C) The authors listed. All rights reserved. No part of this paper may be reproduced in any form, or stored in a retrieval system, without the prior written permission of the author. 


\title{
Price Squeezes as an Exploitative Abuse*
}

\section{Zhijun Chen $^{\dagger}$}

August 09, 2021

\begin{abstract}
Price squeezes have been commonly viewed as an exclusionary abuse under the argument of "constructive refusal to deal", however, such an argument has been challenged by the courts and legal scholars. This paper proposes an exploitative rationale for price squeezes. A vertically integrated dominant firm can exploit efficiency gains from a downstream competitor and price squeezing is a necessary condition for such exploitation. Price squeezing forces the competitor to produce at a lower marginal cost than the dominant firm so that the dominant firm can earn more than the monopoly profit by extracting part of efficiency gains from the rival. Exploitation through price squeezing reduces the rival's profit unfairly and distorts the production efficiency without benefiting consumers. Prohibiting price squeezes benefits the competitor and improves production efficiency without harming consumers. This paper lays a solid economic foundation for treating price squeeze cases and contributes to reconciling the diverging approach adopted by the courts in the United States and the European Union in recent price squeeze cases.
\end{abstract}

Keywords: Price Squeeze, Margin Squeeze, Vertical Integration

J.E.L numbers: D42, L42

*I am grateful to Chongwoo Choe, Bruno Jullien, and Patrick Rey for their constructive discussions and comments.

${ }^{\dagger}$ Monash University. Contact email: chenzj1219@gmail.com. 


\section{Introduction}

A price squeeze (synonymously, margin squeeze in the European Union (EU)) occurs when a vertically integrated firm supplies an indispensable input to its downstream competitors at a price that generates a narrow profit margin that competitors cannot effectively compete with. Price squeeze cases are relatively common. ${ }^{1}$ Many of these cases arise in newly de-regulated sectors particular in telecommunications, but also in the water sector, railways, postal services, pharmaceuticals, pay television, gasoline, funeral services, and dairy industries (amongst others).

Price squeezes have traditionally been regarded as a "constructive refusal to deal", since such practices may cause rivals to exit the downstream market. ${ }^{2}$ However, the viability of this traditional argument has been challenged by the United States (US) Supreme Court's decisions in Pacific Bell Telephone v. linkLine Communications (555 US 438, 2009). In linkLine, the Supreme Court found that the defendant $A T E S T$ did not have a regulatory duty to supply to downstream competitors. If the dominant undertaking has no duty to deal, why should it use a price squeeze as a "constructive refusal to deal" in order to exclude the downstream competitor? A simple refusal to supply would achieve the exclusionary purpose without causing antitrust allegations. Hence, the Supreme Court concluded that the "plaintiffs' price-squeeze claim, looking to the relation between retail and wholesale prices, is thus nothing more than an amalgamation of a meritless claim at the retail level and a meritless claim at the wholesale level."

The European Commission (EC) and European Courts (Courts) adopted a similar approach that treats margin squeezes as a "constructive refusal to supply". However, in a series of decisions related to liberalized telecommunications markets including Deutsche Telekom (T271/03 2008) and Telefonica (C-295/12P, 2014), the EC and Courts endeavored to separate the margin squeeze inquiry from a "constructive refusal to deal" and deemed such practices as an abuse of dominance. The European Court of Justice (ECJ) went a step further and rejected the traditional approach in TeliaSonera (C-52/09, 2011), in which the ECJ faced a similar dilemma as in the linkLine case when it found the dominant undertaking no regulatory liability to supply. TeliaSonera argued that, in the absence of a regulated duty to supply, a margin squeeze case should be considered under the general principles of a refusal to deal. In reply, the ECJ stated

\footnotetext{
${ }^{1}$ According to Wiethaus and Nitsche (2014), there have been 47 price squeeze cases in 21 European countries between 2003 and 2014. In the US, price squeezes have been a recognized but controversial antitrust violation since the Alcoa case in 1945 .

${ }^{2}$ See the discussion of price squeeze cases in Section 5.
} 
that a margin squeeze can "constitute an independent form of abuse distinct from that of refusal to supply" (TeliaSonera, para 56).

However, the ECJ did not provide a rationale for treating margin squeezes as an independent abuse of dominance and the theory of harm for such abuse. The decision was criticized by competition lawyers, including the Advocate General Mazak who argued that if a dominant undertaking could lawfully have refused to provide the products, then it "should not be reproached for providing those products at conditions which its competitors may consider not advantageous. Indeed, it is difficult to see how in such a case the alleged insufficient margin could be anti-competitive." 3

While the courts in both the US and EU found it groundless to deem price squeezes as a "constructive refusal to supply" in the absence of any regulatory obligations to supply, their opinions diverged on whether or not to treat price squeezes as an independent antitrust allegation. Underlying this divergence is a simple but fundamental question which, unfortunately, has been largely ignored by courts and competition authorities: why would a dominant undertaking use a price squeeze if it could simply refuse to supply? The answer appears to be self-evident: the dominant undertaking must find it more profitable using price squeezes than refusing to deal. By refusing to supply, the vertically integrated dominant firm can exclude the downstream competitors and earn a monopoly profit. By price squeezing, it must earn more than a monopoly profit by exploiting the rivals' advantages.

Formally, exploitation occurs if a dominant undertaking can extract efficiency gains from a competitor and earn a higher profit than without the competitor. In this paper, we develop a simple theory of price squeezes that sheds new light on the exploitative nature of the practice. The model captures three key features abstracted from price squeeze cases. First, the dominant undertaking is a vertically integrated entity and is a monopoly (or quasi monopoly) supplier of an indispensable input (or intermediate good) for the downstream products. Second, the downstream firms produce essentially homogeneous final products (Telecommunications and electricity services). Third, competition in the downstream market is asymmetric between the dominant incumbent and the small entrant. Not only does the incumbent have a dominant position, while the entrant often acts as a price taker, they also have different cost structures and comparative advantages. It is quite common that small firms often incur a lower marginal (average) cost than large firms at small scales, but their marginal cost might increase significantly when the business expands.

\footnotetext{
${ }^{3}$ Opinion of Advocate General Mazak in TeliaSonera (ECJ), para 21.
} 
We begin with the baseline model in which a vertically integrated dominant firm faces a competitive fringe entrant in the downstream market. The dominant firm incurs a constant marginal cost because it has already sunk its fixed cost, whereas the entrant firm faces a lower marginal cost than the incumbent in small scales but with a higher marginal cost under large scales. Formally, the dominant undertaking is alleged of price squeezing if the spread of the prices between the final good and the input is in fact below the dominant firm's downstream marginal cost. ${ }^{4}$

We find that price squeezing arises as the equilibrium outcome of profit maximization. Price squeezing forces the competitor to produce at a lower marginal cost than the dominant firm. In this way, the dominant firm can extract part of the efficiency gain and earn a total profit even higher than it would have earned in the absence of the rival (i.e., the monopoly profit). Thus, price squeezing is a necessary condition for exploitation. Exploitation reduces the competitor's efficient production and results in a loss of efficiency. Nevertheless, the production distortion is a by-product of exploitation as the dominant firm has no intention of excluding the competitor.

Hence, a rival can be a source of gain rather than a cause of loss, provided that the dominant firm can manipulate the input price to exploit the rival, and that vertical integration allows such exploitation. We show that exploitation arises under quite general conditions for cost functions, even if the competitor's marginal cost for producing any given quantity is uniformly higher than that of the dominant firm. Intuitively, when a dominant firm's marginal cost of producing the last unit of the monopoly quantity exceeds the rival's marginal cost of producing the first unit, there is an efficiency gain of cost-saving through production reallocation. As long as the competitor is not socially inefficient in production,${ }^{5}$ the dominant firm can always benefit from production reshuffling and extract part of the efficiency gains through price squeezing.

The mechanism of exploitation can be further interpreted as the extraction of the gain from production reshuffling. However, this production reshuffling effect differs from that under a horizontal merger in which the merged firm can fully control the process to minimize the total cost. The vertically integrated dominant firm cannot fully control this production reshuffling process. This reallocation of production is similar to outsourcing: the dominant firm pays the competitor to produce at a per-unit price equal to the rival's marginal cost of producing the last

\footnotetext{
${ }^{4}$ This definition is consistent with the "Equally Efficient Competitor" established by the ECJ in Deutsche Telekom. See detailed discussion in Section 2 and Section 5.

${ }^{5} \mathrm{~A}$ firm is socially inefficient in production if its marginal cost of producing the first unit is higher than the rival's marginal cost of producing the last unit of the monopoly output.
} 
unit. The dominant firm is unable to extract the total efficiency gain from production reshuffling as the competitor retains part of the benefit as its profit. This causes a loss of efficiency as the dominant firm and its competitor are unable to maximize their joint profits.

We also extend the analysis to the asymmetric downstream competition with a strategic competitor, in which the dominant firm is a Stackelberg leader while the entrant is a follower. Price squeezing still arises as an outcome of profit maximization, and it is a necessary condition for exploitation, however, the dominant firm can extract less efficiency rents than facing a competitive fringe entrant. Nevertheless, price squeezing reduces the entrant's profit and distorts production efficiency, and results in a final good price above the monopoly level when the demand function is concave.

Following the Supreme Court's judgement, the opinion of abolishing price squeezes as an independent antitrust allegation becomes dominant among the US legal scholars and competition lawyers. ${ }^{6}$ In contrast, many European legal scholars are in favor of the ECJ's decision to treat prices squeezes as an independent abuse. ${ }^{7}$ While many legal scholars have attempted to propose a new theory of harm about price squeezes, such proposals are based on the exclusionary rationale and a lack of economic foundation. In contrast, this paper develops a robust economic theory and sheds light on the exploitative nature of price squeezes. The theoretical analysis also provides important testable policy implications. We show that exploitation is necessarily accomplished through a price squeeze. The integrated firm can extract efficiency rents in the downstream market only if it sets the price spread between the upstream and downstream below its average cost of producing the residual quantity that was reallocated to the competitor. Banning price squeezes can prevent exploitation and eliminate the efficiency loss due to rentextraction. Prohibiting price squeezes increases the competitor's profit, improves production efficiency downstream without hurting consumers, and increases total social welfare. When the entrant is a strategic rival, the prohibition also reduces the final good price and benefits consumers unambiguously. Thus, our analysis provides a solid economic foundation for the theory of harm of price squeezing, and our findings support the ECJ's decision in treating price squeezes as an independent abuse of dominance.

\section{Related Literature}

Despite an extensive legal literature and numerous comments by competition economists,

\footnotetext{
${ }^{6}$ See Carlton (2008), Sidak (2008), and Hay and McMahon (2012).

${ }^{7}$ See, for instance, Gaudin and Mantzari (2016) and Wiethaus and Nitsche (2014).
} 
there are surprisingly few formal economic studies on price squeezes with two exceptions. Vickers (2010) mentions the potential exploitative effect of price squeezes through a textbook-style illustrative model when discussing competition policy and intellectual property rights. Jullien, Rey, and Saavedra (2014) provide a detailed survey on the economic theories of margin squeezes and also discuss the exploitative use of price squeezes through a stylized model of Bertrand competition in which the dominant firm faces an opportunity cost. In contrast, this paper explores a simple but robust theoretical framework on the exploitative nature of price squeezes and shows that price squeezes can arise as the optimal strategy under quite general conditions. It contributes to the growing literature on rent-extraction pioneered by the seminal paper of Aghion and Bolton (1987) under a vertical relationship where the dominant firm offers the buyer an exclusive dealing contract with stipulated damages to exploit the rival's competitive advantage. The exploitative rationale was further explored by Chen and Rey (2012) in a multiple-product framework where a monopoly supplier of an essential good running its business in an adjacent market adopts a loss-leading strategy to exploit the rival's strength and in this way earns a supra-monopoly profit. In a recent paper, Calzolari and Denicolo (2021) show that the upstream dominant firm can use market-share contracts to extract the rival's efficiency rents and earn more profits than excluding the competitor. These studies shed light on the competitive harm of the exploitative nature: while the dominant firm has no incentives to exclude the rival, its use of exploitative practices leads to partial exclusion of the rival's efficient production and reduces total social welfare.

This paper is also related to the vast literature on vertical integration, in particular, to the Post-Chicago theory of market foreclosure under vertical integration that has developed since the 1980s. Salop and Scheffman (1987) form the basis for this argument, and the work of Ordover, Saloner and Salop (1990) is perhaps the best-known that pioneered the equilibrium analysis of vertical mergers. Riordan (1998) shows that vertical integration makes it credible for the dominant firm to raise the cost of the input to rivals and partially forecloses the fringe firm's production. Such foreclosure improves production efficiency, but raises both the input and final good prices. Other important contributions include Salinger (1988) and Hart and Tirole (1990). This so-called "raising rivals' costs" theory argues that vertical integration alters the pricing incentives of upstream firms and enables the integrated firm to foreclose the competitor by raising its costs. In contrast, Chen (2001) argues that vertical integration may also change the pricing incentive of a downstream firm and the incentive of a competitor in choosing input suppliers, and finds that vertical integration could result in both efficiency gains and a collusive 
effect, which can be procompetitive if the efficiency effect dominates. ${ }^{8}$

Our paper distinguishes itself from the above-mentioned literature in two aspects: first, we find that the integrated firm raises the input price, but also reduces rivals' (marginal) cost of production (the rival is forced to produce as a super competitor). The integrated firm reallocates part of the production to the more efficient rival at a per-unit price equal to the rival's marginal cost for producing the last unit and in this way extracts part of the gain from production reshuffling. Second, while the existing literature is focused on the exclusionary effect of vertical integration, this paper sheds new light on the exploitative effect of price squeezes and examines the welfare effect of such exploitation.

The rest of the paper is organized as follows. Section 2 sets up a simple model to analyze the main results, and the analysis is extended to a setting with more general cost functions in Section 3. We consider quantity competition with a strategic rival in Section 4, and provide a brief summary of legal cases in Section 5. We conclude the paper in Section 6 .

\section{A Simple Theory of Price Squeezes}

An upstream monopoly supplies an intermediate good at a constant marginal cost $\gamma$. The upstream monopoly is also vertically integrated with a dominant downstream firm that produces the final product using the intermediate good as the essential input. Assume that producing one unit of the final product needs one unit of the intermediate good. The dominant firm as an incumbent has already established its capacity and produces the final product at a constant marginal cost $c_{d} \cdot{ }^{9}$ The market for the final product faces a downward sloping demand function $D(p)$, where $p$ is the per-unit price of the final product.

There is a competitive fringe firm entered into a local downstream market as a price taker, The entrant faces a cost function $C_{e}\left(q_{e}\right)$ of producing $q_{e}$ units. Small firms often incur a lower marginal cost than the dominant firm when it operates the business in a small scale and focuses only on local markets. ${ }^{10}$ As their business expands, however, they need to build new capacities

\footnotetext{
${ }^{8}$ Allain, Chambolle, and Rey (2015) find that vertical integration can generate hold-up problems for rivals by affecting both the ex ante and ex post incentives of the integrated supplier.

${ }^{9}$ The main insights and key results hold under general cost functions as discussed in Section 3.

${ }^{10} \mathrm{On}$ the one hand, the incumbent has been operating in the whole country through an established infrastructure and business network, and enjoys a cost advantage at large scales due to economies of scale, whereas the entrant only focuses its business at small scales and cannot afford to invest in nation-wide infrastructure. On the other hand, the incumbent might be obliged to pay higher wages because part of its workforce might be protected by
} 
and hire extra labours, which significantly increases their marginal (average) cost. This feature of cost structures is captured by the following assumption:

Assumption A: The entrant faces an increasing marginal cost $M C_{e}\left(q_{e}\right)$. Moreover, there exists a positive threshold $\bar{q}_{e}>0$ such that $M C_{e}(q)<c_{d}$ for $q_{e}<\bar{q}_{e}$.

\section{Refusal to Supply}

We first consider a benchmark case in which the upstream monopoly refuses to supply the entrant. In this case the vertically integrated firm becomes a monopoly in both upstream and downstream markets and earns a total profit $\pi(p)=\left(p-c_{d}-\gamma\right) D(p)$. Assuming the demand function is not too convex such that the profit function $\pi(p)$ is concave, ${ }^{11}$ the monopoly price $p^{m}$ is uniquely determined by the following first-order condition:

$$
p-c_{d}-\gamma=-\frac{D(p)}{D^{\prime}(p)}
$$

The associated monopoly output and profit are denoted by $q^{m}=D\left(p^{m}\right)$ and $\pi^{m}=\left(p^{m}-c_{d}-\gamma\right) D\left(p^{m}\right)$ respectively. Obviously, the vertically integrated dominant firm will supply the downstream entrant only if it can earn more than the monopoly profit $\pi^{m}$. For precision of presentation, we introduce a definition of exploitation as follows:

Definition 1 Exploitation. Exploitation occurs when a vertically integrated dominant firm extracts efficiency gains from a downstream competitor and earns a higher profit than in the absence of the rival.

\section{Price Squeezes}

Suppose now the upstream monopoly supplies the entrant at a per-unit price $w$ for the intermediate good. The vertically integrated firm sets the prices $w$ and $p$. As a price taker, the entrant chooses its output $q_{e}$ to maximize its profit $\pi_{e}\left(q_{e}\right)=(p-w) q_{e}-C_{e}\left(q_{e}\right)$. The entrant's optimal output is determined when its marginal cost is equal to the price margin between the final and intermediate products:

$$
M C_{e}\left(q_{e}\right)=\rho \equiv p-w,
$$

the rights granted in the context of former state monopolies. In addition, the incumbent might have to bear extra costs related to other activities such as $\mathrm{R} \& \mathrm{D}$, and it is costly to maintain a nation-wide retailing network. In contrast, the entrant only conducts business in some local markets and is more flexible in labor contracts than the incumbent.

${ }^{11}$ This requires $2 D^{\prime}(p)+\left(p-c_{d}-\gamma\right) D^{\prime \prime}(p)<0$. 
The above equation determines the entrant's supply function $q_{e}(\rho)$, which is well-defined and increasing under Assumption A.

Deducting the supply from the entrant firm, the dominant firm then faces a residual demand $D_{d}(p, \rho)=D(p)-q_{e}(\rho)$. The vertically integrated dominant firm's profit comes from two sources: a profit from selling the final product, $\left(p-c_{d}-\gamma\right) D_{d}(p, \rho)$, and a profit from selling the input to the entrant, $(w-\gamma) q_{e}(\rho)$. Its total profit can be expressed as

$$
\begin{aligned}
\Pi(p, \rho) & =\left(p-c_{d}-\gamma\right) D_{d}(p, \rho)+(w-\gamma) q_{e}(\rho) \\
& =\left(p-c_{d}-\gamma\right) D(p)-\left(\rho-c_{d}\right) q_{e}(\rho) \\
& =\pi(p)-L(\rho)
\end{aligned}
$$

where we use $D_{d}(p, \rho)=D(p)-q_{e}(\rho)$ to get the second line. The first term in the third line, $\pi(p)=\left(p-c_{d}-\gamma\right) D(p)$, is the profit that a vertically integrated monopoly would have earned under the refusal to supply, whereas the second term, $L(\rho) \equiv\left(\rho-c_{d}\right) q_{e}(\rho)$, is the foregone benefit due to the supply from the entrant firm. The foregone benefit (the loss) is positive when $\rho=p-w>c_{d}$ but becomes negative when $\rho<c_{d}$, under which a price squeeze arises: ${ }^{12}$

Definition 2 Price Squeezes. A price squeeze occurs when the price margin between the final product and the input, $\rho=p-w$, is less than the dominant firm's downstream marginal cost $c_{d}$.

It is straightforward to see that $\Pi(p, \rho)$ is separable in variables $p$ and $\rho$. Thus, the maximum profit is achieved by choosing $p$ to maximize $\pi(p)$ and choosing $\rho$ to minimize $L(\rho)=\left(\rho-c_{d}\right) q_{e}(\rho)$. However, minimizing $L(\rho)$ necessarily leads to $\rho<c_{d}$, in which case the dominant firm adopts a price squeeze strategy:

Lemma 1 A vertically integrated dominant firm's profit maximization necessarily leads to a price squeeze.

Lemma 1 confirms that a price squeeze arises as a result of profit-maximization. Price squeezing forces the entrant to produce at a smaller scale, associated with a lower marginal cost than the dominant downstream firm: $M C_{e}\left(q_{e}\right)=\rho<c_{d}$. The efficiency rents, as denoted by

\footnotetext{
12 This definition of price squeezes is consistent with ECJ's statement in TeliaSonera, in which the ECJ defines that a margin squeeze arises if the spread between the whole sale price and the retail price is insufficient to cover the specific costs that TeliaSonera must incur in order to supply its own retail services to the end users, so that the spread does not allow a competitor as efficient as the dominant undertaking to compete for the supply of these services to end users. (See TeliaSonera Case C-52/09 para 32.)
} 
$R(\rho) \equiv-L(\rho)=\left(c_{d}-\rho\right) q_{e}(\rho)$, are actually extracted by the dominant firm. Assuming the entrant's supply function $q_{e}(\rho)$ is either concave or not too convex, ${ }^{13}$ the optimal price margin $\rho^{*}$ is determined by the following first-order condition:

$$
\left(c_{d}-\rho^{*}\right) q_{e}^{\prime}\left(\rho^{*}\right)=q_{e}\left(\rho^{*}\right) .
$$

In addition, maximizing $\pi(p)$ leads to the monopoly price $p^{m}$ and the associated monopoly profit $\pi\left(p^{m}\right)$. Thus, the dominant firm's total profit consists of two parts: the monopoly profit $\pi\left(p^{m}\right)$ as if it refused to supply and the efficiency rents $R^{*}=\left(c_{d}-\rho^{*}\right) q_{e}\left(\rho^{*}\right)$ extracted from the entrant:

$$
\begin{aligned}
\Pi^{*} & =\pi^{m}+R^{*}=\pi^{m}+\left(c_{d}-\rho^{*}\right) q_{e}\left(\rho^{*}\right) \\
& =\pi^{m}+\left(c_{d}-\rho^{*}\right)^{2} q_{e}^{\prime}\left(\rho^{*}\right) .
\end{aligned}
$$

It follows that $\Pi^{*}>\pi^{m}$ as $q_{e}^{\prime}(\rho)>0$. Clearly, the dominant firm has no incentives to exclude the entrant, and price squeezes are an exploitative practice rather than an exclusionary conduct. Exploitation occurs only if $c_{d}>\rho$ : hence, price squeezing is a necessary condition for exploitation.

Exploitation results in two types of competitive harm. First, extracting the efficiency rents from the competitor reduces the entrant's profit unfairly. The entrant's profit is reduced by the dominant firm's abuse of upstream monopoly power, not by intensified competition. Solving for the optimal input price gives:

$$
w^{*}=p^{m}-\rho^{*}=p^{m}-M C_{e}\left(q_{e}^{*}\right) .
$$

Substituting into the entrant' profit leads to:

$$
\pi_{e}\left(q_{e}^{*}\right)=M C_{e}\left(q_{e}^{*}\right) q_{e}^{*}-C_{e}\left(q_{e}^{*}\right)=\left(M C_{e}\left(q_{e}^{*}\right)-A C_{e}\left(q_{e}^{*}\right)\right) q_{e}^{*} .
$$

Without exploitation, the entrant would have produced a quantity $\bar{q}_{e}$ such that its marginal cost $M C_{e}\left(\bar{q}_{e}\right)$ is equal to $c_{d}$, and it would have earned a higher profit:

$$
\pi_{e}\left(\bar{q}_{e}\right)=c_{d} \bar{q}_{e}-C_{e}\left(q_{e}^{* *}\right)=\left(c_{d}-A C_{e}\left(\bar{q}_{e}\right)\right) \bar{q}_{e}
$$

Second, rent-extraction distorts the efficiency of production by reducing the entrant's efficient output. As illustrated in Figure 1, the entrant produces $q_{e}^{*}$ at a lower marginal cost, whereas it

\footnotetext{
${ }^{13}$ This requires $\left(c_{d}-\rho\right) q_{e}^{\prime \prime}(\rho)-2 q_{e}^{\prime}(\rho)<0$.
} 
would have produced at least $\bar{q}_{e}$ without rent extraction. The amount of $\bar{q}_{e}-q_{e}^{*}$ is now supplied by the dominant firm at a higher marginal cost $c_{d}$, resulting in an efficiency loss of production.

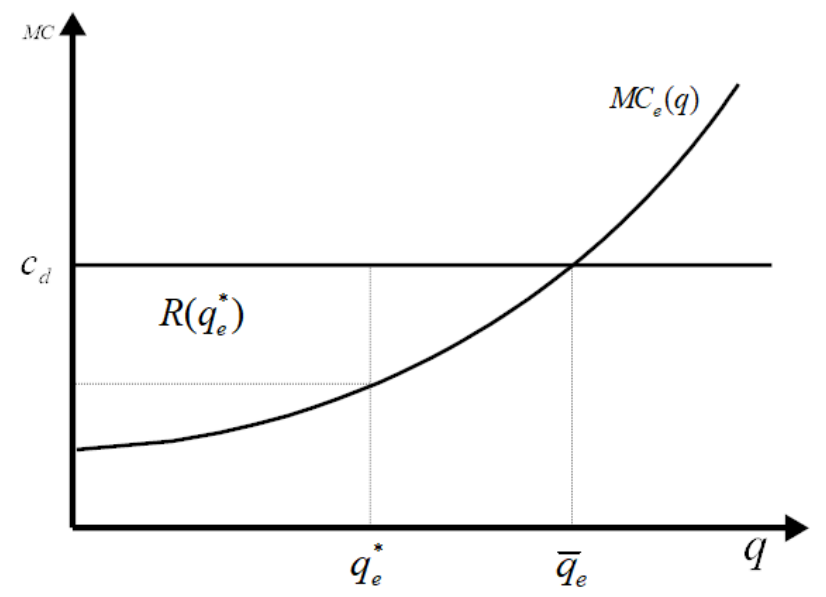

Figure 1: Rent-Extraction

Summarizing the above analysis leads to:

Proposition 1 When a vertically integrated dominant firm faces a downstream entrant with a lower marginal cost at small scales, it adopts a price squeeze strategy to exploit the entrant's efficiency gains and earn a supra-monopoly profit. The dominant firm charges the monopoly price for the final product and sets a high input price as given by (5). Price squeezing reduces the entrant's profit and results in an efficiency loss.

Proposition 1 establishes the exploitative rationale of price squeezes and the theory of competitive harm. It also shows that the dominant firm is shielded from any competitive threats and consumers do not benefit from competition. In particular, the dominant firm still charges the monopoly price in the final product market. ${ }^{14}$ In addition, $p^{m}>c_{d}+\gamma$ also implies the input price above cost $w^{*}=p^{m}-\rho^{*}>c_{d}+\gamma-\rho^{*}>\gamma$. Hence, price squeezes cannot be treated as predatory pricing since both the final and input prices are well-above the cost.

In the linkLine case, following the District Court's judgement that ATET had no antitrust duty to deal with linkLine, the plaintiffs abandoned their price-squeeze claims against ATEST and instead sought to amend their complaint to allege a predatory pricing claim. The plaintiffs

\footnotetext{
${ }^{14}$ When the entrant is a strategic player, the final good price can be either lower or higher than the monopoly price as shown in Section 5.
} 
agreed that their claims must meet the Brooke Group test for predatory pricing. That test established two requirements for predatory pricing: below-cost retail pricing and the feasibility that the defendant could recoup the lost profit losses after exclusion. The Supreme Court found that $A T E S T$ 's retail price remained above cost and dismissed linkLine's complaint of predatory pricing. It concluded that "Where there is no duty to deal at the wholesale level and no predatory pricing at the retail level, a firm is not required to price both of these services in a manner that preserves its rivals' profit margins". ${ }^{15}$

Some legal scholars have attempted to propose a conceptual "above cost predation" test for price squeezes, ${ }^{16}$ however they are unable to establish the feasibility that the predator could recoup the losses incurred during the predation phase by raising the prices after driving the rival out of the market. Indeed, the dominant firm does incur a loss by selling its final product below the actual cost: $p<c_{d}+w$, but this loss is cross-subsidized by the profit from selling its input to the downstream competitor. That is, the dominant firm does not need to recoup its loss after excluding the competitor. In contrast, a more efficient competitor is a source of profits.

Remark 1: It is worth noting that price squeezing is determined by the spread of prices between the input and the final good. It does not matter whether or not the dominant firm can charge the monopoly price for the final good. Suppose there is a price cap $\bar{p}<p^{m}$ for the final good, which may be imposed by the regulator or is due to competitive constraint from a substitute technology in the industry. In equilibrium, the final good price will be set at $\bar{p}$, and price squeezing arises when $\rho=\bar{p}-w<c_{d}$.

Remark 2: Upstream Linear Pricing. In the price squeeze cases, the upstream monopoly often charges a linear price, which is a common feature of de-regulated industries, such as telecommunications and electricity. This is partly because the wholesale prices were set by the regulator before de-regulation, and have been adopted as a standard or tradition in the industry. Another reason for linear pricing is that implementing sophisticated vertical contracts can be quite costly. For instance, lump-sum payments incur significant financial costs as firms often face liquidity constraints. Imposing retail price maintenance and quantity restrictions may cause antitrust concerns with regard to facilitating collusion, and in some situations, it is difficult to monitor the retail price and sales.

\section{Prohibition of Price Squeezes}

\footnotetext{
${ }^{15}$ See Pacific Bell Telephone v. linkLine Communications (2009).Pp 9-12.

${ }^{16}$ See, for example, Gaudin and Mantzart (2016).
} 
The competitive harm of price squeezes as an exploitative abuse can be mitigated by prohibiting such practice. Suppose price squeezes are prohibited and the dominant firm is forced to set $\rho \geq c_{d}$. It will then optimally set $\rho=c_{d}=M C_{e}\left(q_{e}\right)$, implying $q_{e}(\rho)=q_{e}\left(c_{d}\right)=\bar{q}_{e}$. As a result, the entrant produces more and earns a higher profit than without the prohibition. The dominant firm's profit becomes $\Pi(p, \rho)=\pi(p)$, and the constrained maximization leads to $p=p^{m}$ and $w=p^{m}-c_{d}$. Thus, the dominant firm still charges a monopoly price and earns a monopoly profit. Such prohibition has no impact on the final good price and consumer surplus, but the restriction does improve the production efficiency and increases the total efficiency gain: $c_{d} \bar{q}_{e}-C_{e}\left(\bar{q}_{e}\right)>c_{d} q_{e}\left(\rho^{*}\right)-C_{e}\left(q_{e}^{*}\right)$.

Corollary 1 Prohibiting price squeezes improves production efficiency without harming consumers, thus it increases total social welfare.

The prohibition of price squeezes is equivalent to the so-called the Equally Efficient Competitor rule (ECC) recommended by the ECJ as a test for price squeezes. Using the ECC rule requires the dominant firm to charge $w \geq p-c_{d}$, which is equivalent to $\rho \geq p-w=c_{d}$.

\section{General Conditions for Exploitation}

The analysis of price squeezes in the baseline model is built on the assumptions that the dominant firm incurs a constant marginal cost and the competitor faces an increasing marginal cost. One may consider that the dominant firm can exploit the efficiency gains only if the downstream competitor's marginal cost is lower than the dominant firm's marginal cost. One may further argue that such a condition is quite restrictive since in many cases the dominant firm is regarded as more efficient than small competitors. This argument is ad hoc and can be misleading. The fallacy is that one compares the dominant firm's marginal cost with the competitor's marginal cost at the same output levels. Indeed, what matters to rent-extraction is that the competitor's average cost of producing the residual output $q_{e}$ is lower than the dominant firm's wouldbe average cost of producing that amount. For instance, suppose the monopoly output is 20 units and the dominant firm's marginal cost of producing the 20th unit is equal to 10 . If the downstream competitor's marginal cost of producing the first unit is less than 10, then the integrated firm can benefit from outsourcing the production of the last unit to the competitor, and can extract the gain of cost-saving by manipulating the input price.

We examine the conditions for exploitation with general cost functions for the dominant firm. Let $C_{d}\left(q_{d}\right)$ denote the dominant firm's cost functions. With general cost functions, the 
definition of price squeezes must be modified accordingly. Suppose the entrant produces $q_{e}$ units and the dominant firm meets the residual demand $q_{d}=Q-q_{e}$. Then, a vertically integrated firm adopts a price squeeze strategy if it sets the price margin between the final good and the input below its average cost of producing the residual output that it would have produced without the competitor; formally, if

$$
\rho<A C_{d} \equiv \frac{C_{d}(Q)-C_{d}\left(q_{d}\right)}{Q-q_{d}} .
$$

Definition 3 Modified Definition of Price Squeezes. A price squeeze occurs if condition (7) holds.

We now show that the dominant firm can exploit the rival's efficiency gains if and only if it engages in price squeezing. The following assumption of regular conditions is needed for equilibrium analysis.

Assumption B: The cost functions $C_{d}\left(q_{d}\right)$ and $C_{e}\left(q_{e}\right)$ are differentiable and their marginal costs, $M C_{d}\left(q_{d}\right)$ and $M C_{e}\left(q_{e}\right)$, are continuous.

The dominant firm sets $p$ and $w$. As a price taker, the entrant's best response $q_{e}(\rho)$ is determined implicitly by $M C_{e}\left(q_{e}\right)=\rho$. Assumption A ensures that the best response $q_{e}(\rho)$ is well-defined. The dominant firm's total profit can be expressed as:

$$
\Pi(p, w)=p D_{d}(p)-C_{d}\left(D_{d}(p)\right)+w q_{e}(\rho)-\gamma D(p) .
$$

Using $D(p)=D_{d}(p)+q_{e}(\rho)$, we can further rewrite the above profit as:

$$
\begin{aligned}
\Pi(p, w) & =(p-\gamma) D(p)-C_{d}(D(p))+C_{d}(D(p))-C_{d}\left(D_{d}(p)\right)-\rho q_{e}(\rho) \\
& =\pi(p)+\Delta(p, \rho)
\end{aligned}
$$

where $\pi(p)=(p-\gamma) D(p)-C_{d}(D(p))$ is the profit that the dominant firm would have earned without the competitor, and the second term $\left(Q=D(p)=q_{d}+q_{e}\right)$ :

$$
\Delta(p, \rho) \equiv C_{d}(Q)-C_{d}\left(q_{d}\right)-\rho q_{e}(\rho)
$$

is the extra benefit (or loss if negative) that the dominant firm can extract from production reallocation.

The dominant firm can make a monopoly profit $\pi^{m}$ by refusal to supply, in which case it will produce the monopoly output $Q^{m}$ by itself. It can earn a total profit higher than $\pi^{m}$ if $\Delta\left(p^{m}, \rho\right)>0$. That is, if:

$$
\rho<\frac{C_{d}\left(Q^{m}\right)-C_{d}\left(q_{d}\right)}{q_{e}}=\frac{C_{d}\left(Q^{m}\right)-C_{d}\left(q_{d}\right)}{Q^{m}-q_{d}} .
$$


It follows that price squeezing is a sufficient condition for exploitation. In contrast, if price squeezes are prohibited, the dominant firm is forced to set $\rho \geq \frac{C_{d}(Q)-C_{d}\left(q_{d}\right)}{Q-q_{d}}$. In this case, $\Pi(p, w) \leq \pi(p)$ and the dominant firm can earn at most one monopoly profit. Thus, price squeezing is also a necessary condition for exploitation.

The dominant firm may benefit from production reallocation if its marginal cost of producing the last unit of the monopoly output is higher than the competitor's marginal cost of producing the first unit. Under Assumption B, a sufficient condition for profitable production reallocation is given by:

$$
M C_{d}\left(Q^{m}\right)>M C_{e}(0)
$$

where $M C_{d}\left(Q^{m}\right)$ is the dominant firm's marginal cost of producing the last unit of the monopoly output. When $M C_{d}\left(Q^{m}\right)>M C_{e}(0)$, by continuity, there exists a threshold value $\hat{q}_{e}>0$ such that $M C_{d}\left(Q^{m}-q_{e}\right)>M C_{e}\left(q_{e}\right)$ for all $q_{e}<\hat{q}_{e}$. Keeping the total output at $Q^{m}$ (and the price $p^{m}$ ) while reallocating the production of $q_{e}$ units to the entrant, the dominant firm can save its cost as follows:

$$
C_{d}\left(Q^{m}\right)-C_{d}\left(Q^{m}-q_{e}\right)=\int_{Q^{m}-q_{e}}^{Q^{m}} M C_{d}(q) d q>\int_{Q^{m}-q_{e}}^{Q^{m}} M C_{e}(q) d q=\rho q_{e} .
$$

This implies $\Delta\left(p^{m}, \rho\right)=C_{d}\left(Q^{m}\right)-C_{d}\left(Q^{m}-q_{e}\right)-\rho q_{e}>0$ and the dominant firm earns more than monopoly profits: $\Pi\left(p^{m}, w\right)=\pi\left(p^{m}\right)+\Delta\left(p^{m}, \rho\right)>\pi^{m}$. This sufficient condition for exploitation is illustrated in Figure 2:

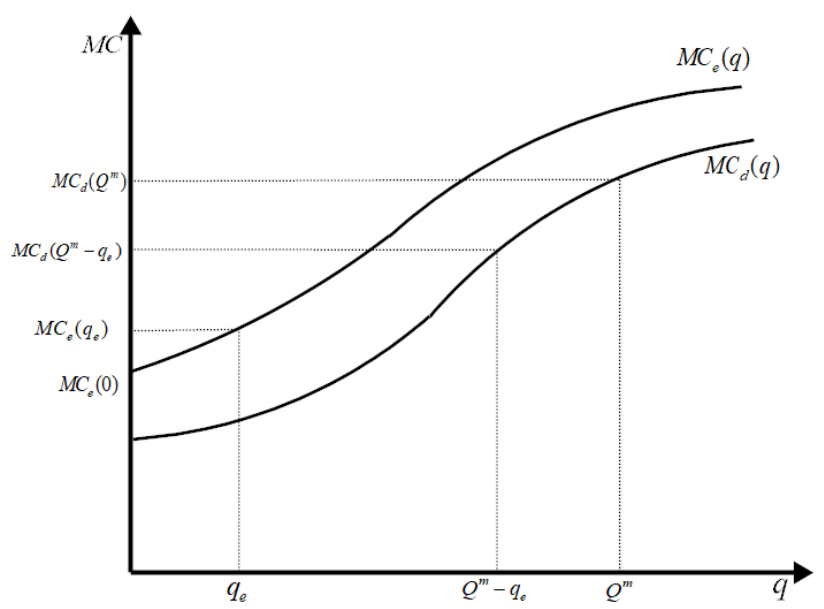

Figure 2: General Cost Functions

Summarizing the above analysis then leads to: 
Proposition 2 Suppose an upstream monopoly is vertically integrated with a downstream dominant firm and competes with a competitive fringe entrant. Under Assumptions B, the dominant firm can exploit efficiency gains from the competitor if and only if it adopts a price squeeze strategy. A sufficient condition for exploitation is given by (9).

The sufficient condition in Proposition 2 indicates that exploitation through price squeezing can happen under quite general conditions and does not require the rival to be more efficient than the dominant firm. Rather, it only requires that the competitor's marginal cost of producing the first unit is less than the dominant firm's marginal cost of producing the last unit of the monopoly output. This holds even if the competitor's marginal cost is uniformly higher than the dominant firm's marginal cost for any output level, that is, if $M C_{e}(q)>M C_{d}(q)$ for any $q$, as long as $M C_{e}(0)<M C_{d}\left(Q^{m}\right)$ (see Figure 2). As long as the competitor is not socially inefficient in production, the dominant firm can always benefit from production reshuffling and extract part of the efficiency gains through price squeezing.

Proposition 2 also establishes that price squeezing is a sufficient and necessary condition for exploitation. The modified definition of price squeezes indicates that the ECJ's efficient component test needs to be carefully examined when the dominant firm's cost structure cannot be represented by a constant marginal cost. In such a test, the courts tend to use a simple formula to calculate the dominant firm's average cost. A common mistake is to compare the price margin $\rho$ with the dominant firm's average cost of producing $q_{d}$ units, $A C_{d}\left(q_{d}\right)=C_{d}\left(q_{d}\right) / q_{d}$, rather than its average cost of producing a would-be quantity $q_{e}$ that is reallocated to the entrant, $A C_{d}\left(q_{e}\right) \equiv\left(C_{d}(Q)-C_{d}\left(q_{d}\right)\right) / q_{e}$, and this mistake could lead to the rejection of a genuine price squeeze claim.

In most cases, the dominant firm operates in nationwide markets while the entrant only supplies to some small local market in which the incumbent is not efficient (for instance, it may be a remote town with a small population). Suppose such local markets only account for $10 \%$ of the total market share. The dominant firm incurs a relatively low average cost in operating the $90 \%$ nationwide markets (say, $A C_{d}\left(q_{d}\right)=10$ ) but a relatively high average cost in serving the extra $10 \%$ small markets (say, $A C_{d}\left(q_{e}\right)=20$ ). If the dominant firm sets the price margin such that $10<\rho<20$, it engages in price squeezing according to our definition, whereas this might not be recognized as a price squeeze allegation following the ECJ's simple approach.

\section{Rethinking the "One-Monopoly-Profit" Theory}

Competition authorities and courts are more concerned about exclusion than exploitation. 
When the monopoly of an essential good extends its business to a competitive segment, it can leverage its market power into the competitive sector and foreclose more efficient rivals. The monopoly can bundle its essential good with a product in an adjacent market or engage in predatory pricing in that market to exclude the competitors. In vertically related markets, the upstream monopoly might refuse to supply to a downstream competitor or use the price squeeze strategy to foreclose the rival. Such exclusionary rationale for the leverage of market power has been quite influential in the courts and on legal scholars.

Price squeezes have been traditionally regarded as a "constructive refusal to deal" in both the US and EU, and the underlying economic theory behind this traditional view is the exclusionary doctrine. However, such exclusionary rationale has been challenged by the courts and legal scholars,${ }^{17}$ using the famous "one monopoly profit theory", associated with the Chicago School: the dominant firm gains nothing from price squeezing since there is only one monopoly profit that the dominant firm could earn by replacing the rival's production.

Unfortunately, the Chicago School's famous one-monopoly-profit theory has been misunderstood and misinterpreted by legal scholars and practitioners in price squeeze cases. This theory was illustrated under the assumptions that competitors produce homogeneous products and face identical constant marginal cost. ${ }^{18}$ That is, a competitor's production does not generate any additional social value. However, this hypothetical environment with homogeneous products and identical constant marginal cost is not often observed in the real world. In most price squeeze cases downstream firms are asymmetric and marginal costs are not constant, even if products or services are essentially homogeneous in industries such as telecommunications. Assuming firms adopt exactly the same technology and face the same cost function, as long as the marginal cost is weakly increasing, there is an efficiency gain for a competitor to produce some quantity, ${ }^{19}$ and such efficiency gains can be exploited by a vertically integrated dominant firm through price squeezing.

\footnotetext{
${ }^{17}$ Carlton (2008) argues that the price squeeze theory leads to no competitive harm and thus using the theory of price squeeze to create antitrust liability is likely to chill competition and harm consumers.

${ }^{18}$ See Carlton (2008), page 275.

${ }^{19} \mathrm{~A}$ simple textbook example in microeconomics tells us that a monopolist can benefit from allocating its production into two identical factories when it faces a convex cost function.
} 


\section{Quantity Competition with a Strategic Entrant}

The dominant firm's capacity of rent-extraction will be constrained when the entrant becomes a strategic rival. Whether or not price squeezes will arise and the impact of banning such practice needs to be further studied. Consider now a dominant firm competing with a strategic downstream entrant. The dominant firm still enjoys an advantageous position in the downstream market. We model such asymmetric competition using a Stackelberg leader-follower setting. ${ }^{20}$ The timing of the game is illustrated as follows: in Stage 1, the dominant firm sets the input price $w$. In Stage 2, the dominant firm chooses its quantity of the final good $q_{d}$ first, followed by the entrant's choice of quantity $q_{e}$. Let $P(Q)$ denote the inverse demand function for the final good associated with the demand function $Q=D(p)$, where $Q=q_{d}+q_{e}$ is the total supply. We assume that the inverse demand function is not too convex such that the entrant's best response is well defined and the profit function $\pi(Q)=\left(P(Q)-c_{d}-\gamma\right) Q$ is concave.

Assumption C: The inverse demand function $P(Q)$ satisfies $P^{\prime}(Q)+P^{\prime \prime}(Q) Q<0$.

The dominant firm has a first-mover advantage by setting the input price $w$ and choosing the quantity $q_{d}$ first and it operates as the Stackelberg leader in the downstream market. After observing $w$ and $q_{d}$, the entrant chooses its output $q_{e}$ as a Stackelberg follower to maximize its profit $\pi_{e}\left(q_{e}\right)=(P(Q)-w) q_{e}-C_{e}\left(q_{e}\right)$. Solving for the entrant's best response as the function of $q_{d}$ and $w$ leads to:

$$
M C_{e}\left(q_{e}\right)-P^{\prime}(Q) q_{e}=P(Q)-w
$$

Recall that a competitive fringe entrant's output is determined by $M C_{e}\left(q_{e}\right)=\rho=P(Q)-w$, whereas here the strategic entrant's output is determined such that its marginal cost is less than the price margin $\rho$. Thus, the strategic entrant will produce less output than a competitive fringe entrant would have produced given the same margin $\rho$. This is because the Stackelberg follower is not a price taker; rather it will take into account its impact on the final good price.

Under Assumption C, the entrant's best response, as denoted by $q_{e} \equiv q_{e}\left(q_{d}, w\right)$, is determined by equation (10). Taking into account the entrant's best response, the dominant firm chooses $w$ and $q_{d}$ to maximize its total profit:

$$
\begin{aligned}
\hat{\Pi}\left(q_{d}, w\right) & =\left(P(Q)-c_{d}\right) q_{d}+w q_{e}-\gamma Q \\
& =\left(P(Q)-c_{d}-\gamma\right) Q-\left(P(Q)-w-c_{d}\right) q_{e} \\
& =\pi(Q)-\left(P(Q)-w-c_{d}\right) q_{e}\left(q_{d}, w\right)
\end{aligned}
$$

\footnotetext{
${ }^{20}$ Chen, Jullien, and Rey (2017) also show that the analysis of price squeezes is robust when downstream firms are the Cournot duopoly.
} 
where $\pi(Q)=\left(P(Q)-c_{d}-\gamma\right) Q$ represents the dominant firm's total profit in the absence of the entrant and the second term, $\left(P(Q)-w-c_{d}\right) q_{e}\left(q_{d}, w\right)$, is the foregone benefit due to competition.

Two observations can be made immediately. First, profit maximization necessarily leads to $P(Q)-w<c_{d}$ and price squeezing still arises as an optimal strategy. Price squeezing forces an entrant to produce at a lower marginal cost than the dominant firm: $M C_{e}\left(q_{e}\right)=$ $P(Q)-w+P^{\prime}(Q) q_{e}<c_{d}+P^{\prime}(Q) q_{e}<c_{d}$. Second, given the same price margin $\rho$, a strategic entrant produces less than a competitive fringe entrant; hence, the dominant firm extracts less efficiency rents than when facing a competitive fringe entrant.

While a strategic entrant can limit the dominant firm's capacity of rent-extraction, this does not necessarily benefit consumers. The final output of this Stackelberg equilibrium $Q^{*}$ can be either higher or lower than the monopoly level $Q^{m}$, depending on the shape of the demand function. Suppose the dominant firm wants to achieve the monopoly output $Q^{m}$ so as to maintain the monopoly price $p^{m}$, and moreover sets the input price at $w^{*}$ as before. Facing the same price margin $\rho=p^{m}-w^{*}$, the Stackelberg follower produces less than the competitive fringe and the dominant firm can extract less efficiency rents. Then, the dominant firm will raise the price margin $\rho=P(Q)-w$ so as to increase the entrant's output $q_{e}$, by either reducing output $q_{d}$ or decreasing $w$. Doing so results in a higher total output (lower final price) than the monopoly level when the inverse demand function is convex, whereas a lower total output (higher final price) when the inverse demand function is concave.

Substituting the entrant's best response equation (10), we can rewrite the dominant firm's profit function as:

$$
\hat{\Pi}\left(q_{d}\right)=\pi(Q)-\left(M C_{e}\left(q_{e}\right)-P^{\prime}(Q) q_{e}-c_{d}\right) q_{e}
$$

The dominant firm's optimal output $q_{d}^{*}$ (note that $q_{d}^{*}=Q^{*}-q_{e}^{*}$ ) is determined by the following first-order condition

$$
\pi^{\prime}\left(Q^{*}\right)=-P^{\prime \prime}\left(Q^{*}\right)\left(q_{e}^{*}\right)^{2}
$$

It follows that $\pi^{\prime}\left(Q^{*}\right)>0$ if and only if $P^{\prime \prime}\left(Q^{*}\right) \leq 0$. Recall that $\pi^{\prime}\left(Q^{m}\right)=0$ for the monopoly output $Q^{m}$. Thus, the final output $Q^{*}$ is higher than the monopoly output $Q^{m}$ (i.e., $p^{*}<p^{m}$ ) if the inverse demand function is convex, since convex demand means that price changes have a large impact on quantity. In contrast, the final output is lower than $Q^{m}$ (i.e., $p^{*}>p^{m}$ ) if the demand is concave since concave demand means that the price changes have a small impact on quantity.

Summarizing the above analysis leads to: 
Proposition 3 Suppose the dominant firm faces a strategic entrant as a Stackelberg follower. The dominant firm adopts a price squeeze strategy to exploit the entrant's efficiency gains and earns more than monopoly profits. The dominant firm earns less profits than facing a competitive fringe entrant. Consumers face a higher (resp. lower) final product price than the monopoly level if the inverse demand function is concave (resp. convex).

Proof. See Appendix A.

\section{Prohibition of Price Squeezing}

We now examine the impact of banning price squeezes. When price squeezing is not allowed, the dominant firm must choose $w$ and $q_{d}$ such that $P(Q)-w \geq c_{d}$. Suppose the ban is implemented through the input price, in which the dominant firm is obliged to set input price such that $w \leq P(Q)-c_{d}$. The dominant firm chooses $w$ and $q_{d}$ to maximize its profit, $\hat{\Pi}\left(q_{d}, w\right)=$ $\pi(Q)-\left(P(Q)-w-c_{d}\right) q_{e}\left(q_{d}, w\right)$, subject to the constraint $w \leq P(Q)-c_{d}$. It is straightforward to check that $\partial \hat{\Pi}\left(q_{d}, w\right) / \partial w>0$ under this constraint and the optimal input price is bounded by the constraint $w=P(Q)-c_{d}$. Thus, prohibiting price squeezing reduces the input price and increases the entrant's output. We show in Appendix B that banning price squeezing increases total output and reduces the final good price, regardless of the shape of the demand function. It appears that the prohibition benefits the competitor and consumers, and also increases the production efficiency.

Given $P(Q)=w+c_{d}$, the equilibrium output satisfies $\pi^{\prime}(\hat{Q})=P^{\prime}(\hat{Q}) \hat{q}_{e}<0$. Hence, the total output exceeds the monopoly level and the final price is less than the monopoly price. This also implies that the dominant firm earns less than the monopoly profit: $\hat{\Pi}\left(q_{d}, w\right)=\pi(\hat{Q})<$ $\pi^{m}$. This raises a concern that the vertically integrated firm might exclude the competitor by refusing to deal. Hence, the prohibition of price squeezes should be accomplished with an obligation to supply.

Proposition 4 Suppose the dominant firm faces a strategic entrant as a Stackelberg follower. Prohibiting price squeezes prevents the dominant firm from exploitation and benefits the competitor and consumers, and improves production efficiency as well. The final good price is below the monopoly level and the dominant firm earns less than the monopoly profit.

Proof. See Appendix B.

\section{Illustrative Example}


Consider an illustrative example with constant marginal cost $c_{e}=c_{d}-\delta$, where $\delta>0$ measures the entrant's cost advantage, and the linear demand $P(Q)=a-b Q$. The entrant's best response (10) can be simplified as:

$$
P(Q)-w-c_{e}=b q_{e}
$$

From (12), the total output is the same as the monopoly quantity $Q^{m}=\frac{a-c_{d}-\gamma}{2 b}$, and consumers face the monopoly price $p^{m}=\frac{a+c_{d}+\gamma}{2}$. Moreover, differentiating $\hat{\Pi}\left(q_{d}, w\right)$ with respect to $w$ and solving for FOC, we obtain:

$$
P(Q)-w-c_{d}=-b q_{e}
$$

Then, solving for the equilibrium price margin leads to:

$$
\rho^{*}=P(Q)-w=c_{d}-\frac{\delta}{2},
$$

implying $\rho^{*}-c_{d}=-\frac{\delta}{2}$.

The entrant's output is given by:

$$
q_{e}^{*}=\frac{\delta}{2 b}
$$

Clearly, the entrant will be accommodated if and only if $\delta>0$. The dominant firm extracts efficiency rents:

$$
R^{*}=\left(\delta-b q_{e}\right) q_{e}=\frac{\delta^{2}}{4 b}
$$

leaving the entrant a profit $\pi_{e}^{*}=R^{*}$.

\section{Applications to Price Squeeze Cases}

While the Courts in both the US and EU have traditionally shared the common view of treating price squeeze cases, recent decisions in several prominent cases have shown the clear divergence of their approaches. In this section, we provide a brief summary of price squeeze cases in the US and EU. ${ }^{21}$ We also provide a case study of price squeezes from the dairy industry in New Zealand with a relatively detailed discussion. ${ }^{22}$

\footnotetext{
${ }^{21}$ Hay and McMahon (2012) provide an in-depth analysis of the diverging approach to price squeezes in the U.S. and Europe. The discussion in the Subsection 5.1 is based on their analysis.

${ }^{22}$ This case study is based on my working paper "Vertical Integration and Rent-Extraction: Lessons from the Dairy Industry" (2020).
} 


\subsection{Summary of Price Squeeze Cases}

\section{Price Squeeze Cases in the US}

In the US, price squeezes have been traditionally regarded as a variant of a "constructive refusal to deal" and treated against the background of the law on "refusals to deal" under Section 2 of the Sherman Act. The classic duty to deal doctrine was established in United States v. Colgate \& Company (250 US 300, 1919), where the Supreme Court stated that there might exist a duty to deal in the circumstances where a company seeks to create or maintain a monopoly.

The classic formulation of antitrust liability for a price squeeze is put forward by Judge Learned Hand in United States v. Aluminum Co. of America (148 F.2d 416 (2d Cir.1945)). The Aluminum Co. of America (Alcoa) was accused of using its monopoly power in the upstream aluminum ingot market to squeeze the profits of competitors in downstream aluminum sheet manufacturing. In spite of the fact that the industry was not regulated and Alcoa held no liability to supply, the Court stated that a vertically integrated dominant firm must charge downstream competitors not more than a "fair price" for its essential input and ensure its downstream competitor a "living profit". Judge Hand used Alcoa's costs as the benchmark and asked whether the integrated firm Alcoa's downstream fabricating division could make a profit at the current price if it had to buy Aluminum ingot at Alcoa's upstream price. This conceptual test is indeed equivalent to the "Equally Efficient Competitor" (ECC) test used by the European Commission and the ECJ in Deutsche Telekom.

Judge Hand's view of ensuring the rival a "living profit" was criticized as an approach of protecting the competitor not competition, which is irreconcilable with the consumer-welfare objective of modern competition laws. ${ }^{23}$ His opinion of treating price squeezes as an antitrust allegation in Alcoa was essentially rejected by the Supreme Court in Verizon Communications v. Law Offices of Curtis V Trinko (540 US 398, 2004), which states "Given development in economic theory and antitrust jurisprudence since Alcoa, we find our recent decisions in Trinko and Brooke Group more pertinent to the question before us."

Moreover, the Supreme Court's decision in Trinko has significantly reduced the circumstances where a duty to deal can be established under Section 2 of the Sherman Act, particularly in regulated industries and/or where there has been no previous course of dealing. Under Trinko, the vertically integrated local exchange carrier Verizon was accused of providing insufficient

\footnotetext{
${ }^{23}$ See Sidak (2008) for a detailed discussion.
} 
service assistance to its competitors in the regulated market. In its decision, the Supreme Court pronounced two important opinions. First, the Supreme Court states that the existence of a regulation does not create an antitrust duty to deal for Verizon. The Supreme Court placed a great deal of emphasis on the absence of a prior supply agreement between Verizon and Trinko under regulation. Second, it suggests that if a firm has no duty to deal with its competitors at wholesale, it has no duty to deal under conditions that would benefit the rivals.

The Supreme Court's decision in Trinko was further reinforced in linkLine, which diminishes the likelihood of a successful claim of price squeezes. In linkLine, the vertically integrated company ATEST was alleged by linkLine and several other internet service providers (ISP) of setting a high wholesale price for digital subscriber line (DSL) access and a low price for its retail broadband internet services, which squeezed the profit margins of the plaintiffs. ATEST was accused of "preserve and maintain its monopoly control of DSL access to the Internet." At the time of the complaint, $A T \mathscr{B} T$ was required by regulation to supply the wholesale service at a reasonable and non-discriminatory rate. The regulation ceased when it was deemed that sufficient competition had been introduced downstream.

The district court and the Court of Appeals for the Ninth Circuit ruled that the plaintiffs had a potentially valid claim under section 2 of the Sherman Act. On appeal, the Supreme Court, rather than looking at the price squeeze as a single concept, broke it into two component parts: the wholesale price and the retail price. First, the Court stated that the defendant ATEST had no duty to deal at all (in accordance with Trinko), since it had never voluntarily engaged in selling at the wholesale level. Because $A T E S T$ had no duty to deal, it did not have a duty to sell at a reasonable wholesale price, and the plaintiffs' claim of high wholesale price was groundless. Second, the Court also dismissed the plaintiffs' claim that the retail price was too low, because the claim did not meet the requirements for predatory pricing established in Brooke Group: that is, the defendant's retail prices are below a relevant measure of costs for the vertically integrated entity and there is a "dangerous probability" that they will recoup any lost profits from the period of predation. Thus, the decision in linkLine essentially abolished the price squeeze as a stand-alone antitrust allegation in the US.

\section{Price Squeeze Cases in EU}

In its Guidance on the Commission's Enforcement Priorities in Applying Article 102 (2009), the EC states that it regards a margin squeeze as a form of "constructive refusal to deal" and requires the establishment of the elements of a duty to deal under Article 102. The EU courts have imposed such a duty under Article 102 in a number of decisions prior to Deutsche Telekom, 
including Oscar Bronner (E.C.R. I-7791, 1998). Under Oscar Bronner, for a refusal to supply under Article 102, the ECJ required that the refusal must be likely to eliminate all competition in the relevant market, the service in itself must be indispensable, and the refusal must be incapable of being objectively justified.

However, in a serious of recent decisions in liberalized telecommunications markets, the EU courts have attempted to separate the margin squeeze inquiry from a "constructive refusal to deal". In Deutsche Telekom (2003), ${ }^{24}$ the European Commission established that the Equally Efficient Competitor (EEC) imputation test is the appropriate approach for margin squeeze cases. It assesses the undertaking pricing practices on the basis of its own charges and costs, rather than on the basis of actual or potential competitors. The key difficulty with the concept of EEC is that it does not correspond to either an exclusionary purpose or to a finding of competitive harm to consumers. Recognizing this difficulty, the General Court in its decision on Deutsche Telekom's appeal in 2008 further stated that the abusive nature of the incumbent's conduct is directly connected with the "unfairness" of the spread between its prices for wholesale access and its retail prices, which takes the form of a margin squeeze. From this perspective, it was not required to demonstrate that retail prices are predatory or that input prices are excessive, qualifying it as a stand-alone antitrust infringement. Referring to the requirement of refusal to deal under Oscar Bronner, the General Court further argued that the abusive effects of margin squeezes can in principle be derived from the fact that the incumbent's input is regulated and is regarded as indispensable for competition. ${ }^{25}$

There is no doubt that Deutsche Telekom had a regulatory duty to supply. However, in the absence of a regulatory duty to supply, is it a requirement for a margin squeeze in the EU to establish the elements of a refusal to supply, or is a finding of the insufficient price spread under the EEC test enough? This issue arises in the ECJ's preliminary ruling on TeliaSonera. TeliaSonera was charged with pricing its wholesale access services to competitors and its broadband ADSL internet services to end users at prices that were insufficient to cover the incremental cost

\footnotetext{
${ }^{24}$ Following liberalization, Deutsche Telekom was required to offer entrants in the German telecommunications market fully unbundled wholesale access to the local loop. Its wholesale charges and retail rates for analogue and broadband were subject to some form of regulation by the German telecommunications authority. Even if the wholesale and retail prices are under regulation, Deutsche Telekom still had a commercial discretion to construct its tariffs. Deutsche Telekom was accused by some competitors, such as Vodafone, of margin squeezing, whereby Deutsche Telekom has set its wholesale price at such a level that they were unable to obtain wholesale access and profitably sell retail access services in competition with Deutsche Telekom's own retail access services.

${ }^{25}$ Deutsche Telekom AG v Commission of the European Communities, Case T-271/03 (2008), para 237.
} 
that it had to incur in providing end user services. The wholesale and retail services, unlike those in Deutsche Telekom, were not subject to regulation.

The ECJ confirmed that the test for a margin squeeze was that of "as efficient competitor" and that there was no need for the wholesale and retail prices to be abusive in themselves or that any losses be capable of recoupment. TeliaSonera argued that, in the absence of a regulatory duty to supply, the test for a margin squeeze had to go beyond the mere finding of an insufficient price spread and should be considered under the general principles of a refusal to supply as established in Oscar Bronner. In reply, the ECJ stated that a margin squeeze can "constitute an independent form of abuse distinct from that of refusal to supply" and there was no need to apply the elements as set out in Oscar Bronner in the absence of a regulatory duty to supply. The test for a margin squeeze in the EU is therefore solely focused on the spread between the wholesale and retail prices.

Both the Supreme Court's decision in Trinko and linkLine and the ECJ's decision in TeliaSonera have rejected the traditional view of treating a price squeeze as a "constructive refusal to deal". This is equivalent to the rejection of the exclusionary doctrine of price squeezing. However, the Supreme Court and the ECJ then diverged in their approach treating a price squeeze in the absence of the exclusionary doctrine. The Supreme Court essentially abandoned price squeezes as an antitrust liability; in contrast, the ECJ's decision in TeliaSonera established margin squeezes as an independent abuse of dominance.

In linkLine, the Supreme Court rejected the exclusionary rationale of price squeezes based on a simple argument: "Had ATEST simply stopped providing DSL transport service to the plaintiffs, it would not have run afoul of the Sherman Act." However, the Supreme Court did not ask another related question: Why would $A T \mathscr{B} T$ still supply to its downstream competitor when it could simply refuse to deal? Ignoring this question leads to several errors in its judgement. First, as we have shown that the vertically integrated dominant firm can make more profit from dealing with a downstream competitor, the duty to supply is therefore not a binding constraint here: in other words, whether or not there is a duty to deal is not relevant to price squeezing. Second, in the linkLine case, the Supreme Court insisted that the price squeeze claims must meet the Brooke Group requirements for predatory pricing. The Supreme Court compared ATEST's retail price with its average cost, and concluded that the price is above the cost. This calculation was misleading. As we have shown in Proposition 1, the vertically integrated dominant firm sets the price spread between the upstream and downstream below its marginal cost: $\rho=p-w<c_{d}$, 
and subsidizes the loss by its profit from the upstream. Because it can make more than monopoly profit through price squeezing, its retail price is always above the total cost: $p>c_{d}+\gamma$.

The ECJ's decision in TeliaSonera declares margin squeezes as an independent antitrust infringement, but it does not provide a rationale for such abuse of dominance and the theory of harm. It was criticized by competition lawyers including the Advocate General Mazak as well as legal scholars. Hay and McMahon (2012) argue that the decision significantly broadens the potential liability for a margin squeeze in the EU and significantly increases the risk of "false positive" in these cases. They further comment that the EEC test translates neither into an exclusionary purpose nor into consumer detriment. Our paper provides an economic foundation for the ECJ's decision and confirms that price squeezing is a stand-alone antitrust infringement: it is an exploitative abuse not an exclusionary abuse of dominance. We show that a necessary condition for such exploitation is that the price spread between the downstream and upstream is set below the dominant firm's own marginal or average cost, and the "Equally Efficient Competitor" test established by the EC and the ECJ is appropriate in price squeeze cases.

\subsection{The Fonterra Case}

Price squeeze cases are also common in some agricultural sectors where farmer-owned cooperatives become a monopoly supplier and are also vertically integrated with a dominant downstream processor. One recent case is from the dairy industry in New Zealand, in which the world's largest dairy supplier Fonterra was accused of price squeezing. Fonterra as a vertically integrated dairy cooperative established its quasi-monopoly position in raw milk production (with $95 \%$ of total market share) in 2001. Fonterra is regulated by New Zealand's Ministry of Agriculture and Forestry (MAF), and is obliged to supply approximately $5 \%$ of its total collection of raw milk to independent milk processors who compete with its vertical subsidiary Fonterra Brands in the downstream market. In this case, Fonterra has a regulatory duty to supply, but the raw milk price is set according to the so-called Milk Price Manual designed by Fonterra.

In 2008, Fonterra adopted a new pricing manual based on the so-called Hypothetical Efficient Competitor (HEC) model. According to this approach, the raw milk price is set to be the difference between the output price and the average production cost of a "notional" processor. According to Deloitte's report, this notional producer appears to be a "super competitor" that combines the best features of an independent firm's ability. It is estimated by Deloitte that Fonterra sets the average processing cost for the notional producer at about $\$ 0.50$ per $\mathrm{kg}$ of 
milk solids (kgMS) less than Fonterra could achieve, which is approximately half the operating profit margin of an efficient independent firm. ${ }^{26}$ Fonterra's HEC approach is a typical practice of price squeezing: $w=p-M C_{e}\left(q_{e}\right)>p-c_{d}$ implies $\rho=p-w<c_{d}$, where $M C_{e}\left(q_{e}\right)$ is the marginal (average) cost of a "notional" competitor.

The independent firms suffered considerably from the inflated raw milk price. They raised concerns to the Commerce Commission and MAF. In its regulatory impact statement (2012), MAF was also concerned that the raw milk price was raised by Fonterra above the efficient milk price level. However, MAF argued that this result could be interpreted as Fonterra paying out a higher than efficient farm gate milk price - at the expense of its own profit, and concluded that Fonterra's current milk price manual was conceptually consistent with a milk price that would emerge in a competitive market for farmers' milk.

Our simple theory can explain the exploitative nature of Fonterra's HEC approach. In the dairy market, collecting raw milk from farms incurs significant costs. A small independent firm may build its processing plant close to some big farms to save the collection costs. When output expands, it must collect raw milk from other farms further away, and this could increase its costs significantly. In contrast, Fonterra is obliged to collect the raw milk from all of its member farmers including those in more remote areas. This suggests that the independent processors can be more efficient than Fonterra on a small scale by focusing on some regional market.

Fonterra's raw milk price is set equal to the independent firm's profit margin $w=p-$ $M C_{e}\left(q_{e}\right)$, which is higher than the dominant firm's profit margin $p-c_{d}$. Denoting by $\lambda \equiv$ $c_{d}-M C_{e}\left(q_{e}\right)$ the efficiency gain from the fringe firm, Fonterra's HEC equation can be further expressed as $w=p-M C_{e}\left(q_{e}\right)=p-c_{d}+\lambda$. Thus, Fonterra uses the HEC model to exploit the efficiency gain $\lambda$ from the competitor. Such exploitation squeezes the independent processors' profit margin and reduces their efficient production.

According to Deloitte's estimation, the efficiency gain $\lambda$ ranges from NZ $\$ 0.40$ to NZ $\$ 0.50$ per kgMS. In the 2011 financial year, the independent firms processed 75 million kgMS raw milk, which accounted for $5 \%$ of Fonterra's total supply of 1,500 million kgMS. A back-of-the-envelope calculation thus indicates that Fonterra has extracted about NZ $\$ 30$ million to NZ $\$ 37.5$ million from the independent firms, which contributes to around $5 \%$ to $6 \%$ of Fonterra's profit before tax. ${ }^{27}$ Noting that the independent firms only possess $5 \%$ of Fonterra's total raw milk supply,

\footnotetext{
${ }^{26}$ See the Summary of Deloitte's Analysis of Fonterra's Milk Price (2012). Available upon request.

${ }^{27}$ According to the Fonterra Annual Report (2012), Fonterra's profit before tax was \$622 million in 2011. The report is available at: https://www2.fonterra.com/files/financial-docs/presentations/2012-annual-results-
} 
Fonterra exploited a significantly large share of efficiency gains from the competitors.

The above analysis is summarized in the following corollary.

Corollary 2 The HEC approach adopted by Fonterra is a typical price squeeze practice to exploit efficiency gains from independent processors. It squeezes competitors' profit margin and reduces their efficient production.

The New Zealand dairy industry is regulated by the Ministry of Agriculture and Forestry (now called the Ministry of Primary Industries) according to the Dairy Industry Restructuring Act (DIRA). Under current regulations, Fonterra is obliged to supply up to 600 million liters of raw milk per season (about $5 \%$ of its total collection) to independent firms at the same raw milk price that Fonterra pays to its farmers. The raw milk price is set by Fonterra according to the so-called Milk Price Manual. Both MAF and the Commerce Commission argue that this obligation of supply could prevent Fonterra from exercising market power against independent firms. However, this duty to supply does not prevent Fonterra from exploitation, since the DIRA "generally allows Fonterra to exercise wide discretion in making what are very technical and necessarily subjective input decisions". Fonterra's pricing manual is reviewed by the Commerce Commission each year. However, the regulator's recommendations are not mandatory for Fonterra: ${ }^{28}$

"To avoid the risk of regulatory error arising from asymmetric information, the Commerce Commission's findings are not binding on Fonterra's benchmark price calculation. Instead, they are designed to provide an informed public commentary by a credible and independent expert, with access to commercially sensitive information, to promote transparency of Fonterra's necessarily subjective assumptions that underpin the benchmark price calculation."

In May 2019, the DIRA was reviewed by the Ministry of Primary Industry of New Zealand. One of the main focuses of the review was to reform Fonterra's raw milk pricing approach. The Ministry acknowledges that there is an opportunity to improve Fonterra's benchmark milk pricing calculation. Indeed, in its yearly review 2017/2018, the Commerce Commission identified that Fonterra's estimation of the cost for a notional firm was too low and the resulting raw milk price was too high, which could reduce the profitability of the independent firms. The Ministry presentation-26-september-2012-1-.pdf.

${ }^{28}$ See "Modifying Fonterra's obligations under the Dairy Industry Restructuring Act 2001 (DIRA) regulatory regime", page 35; https://www.mpi.govt.nz/law-and-policy/legal-overviews/primary-production/dairy-industryrestructuring-act/dairy-industry-restructuring-act-2001-review/. 
recommends amending the DIRA to reduce Fonterra's discretion in setting a key assumption (asset beta) underpinning the benchmark price calculation. In particular, it requires Fonterra's estimation of cost to be based on the milk processing operations of a "real" firm rather than a "notional" competitor. ${ }^{29}$ The recommendation is consistent with the EEC rule established by the European Commission. Implementing this recommendation would force Fonterra to set the raw milk price $w=p-c_{d}$ and independent processors can produce more output $q_{e}$ such that $M C_{e}\left(q_{e}\right)=p-w=c_{d}$. Provided that the Commerce Commission can estimate and calculate the average cost of milk processing adequately, this reform could prevent rent extraction by Fonterra and achieve an efficient output level.

\section{Conclusions}

This paper proposes an exploitative rationale for price squeezes. A vertically integrated dominant firm can exploit the efficiency gains from a downstream competitor and price squeezing is a necessary condition for such exploitation. The mechanism of exploitation is similar to production reshuffling, in which the dominant firm reallocate part of its production to a downstream rival in order to save on production costs. The dominant firm can extract part of the efficiency gains from the competitor by raising the input price such that the spread of the input and final good prices is set below its downstream marginal cost. We show that the dominant firm can earn more than the monopoly profit through price squeezing and therefore it has no incentives to exclude the competitor. Nevertheless, exploitation through price squeezing reduces the rival's profit unfairly, and distorts the production efficiency without benefiting consumers. Prohibiting price squeezes can benefit the competitor and improve production efficiency, without harming consumers and, thus, unambiguously increases total social welfare.

We show that exploitation through price squeezing arises under very general conditions for production costs and the analysis is robust when the downstream entrant is a strategic rival. Hence, this paper establishes a solid economic foundation for the analysis of price squeeze cases and provides testable implications for competition policy. Our analysis contributes to reconciling the diverging approach adopted by the courts in the US and EU in recent price squeeze cases.

\footnotetext{
${ }^{29}$ See "Modifying Fonterra's obligations under the Dairy Industry Restructuring Act 2001 (DIRA) regulatory regime", page 37; https://www.mpi.govt.nz/law-and-policy/legal-overviews/primary-production/dairy-industryrestructuring-act/dairy-industry-restructuring-act-2001-review/.
} 


\section{Appendix A: Proof of Proposition 3}

We show first that the competitor's best response function is well-defined and decreases in $w$ and $q_{d}$ under the assumption $P^{\prime}(Q)+P^{\prime \prime}(Q) Q<0$. The entrant's profit is given by $\pi_{e}\left(q_{e}\right)=(P(Q)-w) q_{e}-C_{e}\left(q_{e}\right)$. The second-order derivative is:

$$
\pi_{e}^{\prime \prime}\left(q_{e}\right)=2 P^{\prime}(Q)+P^{\prime \prime}(Q) q_{e}-M C_{e}^{\prime}\left(q_{e}\right)
$$

Since $2 P^{\prime}(Q)+P^{\prime \prime}(Q) q_{e}<0$ if $P^{\prime \prime}(Q)<0$, and $2 P^{\prime}(Q)+P^{\prime \prime}(Q) q_{e}<P^{\prime}(Q)+P^{\prime \prime}(Q) Q<0$ if $P^{\prime \prime}(Q)>0, \pi_{e}^{\prime \prime}\left(q_{e}\right)<0$. Hence, the best response, $q_{e}\left(q_{d}, w\right)$, is determined by the following first-order condition:

$$
M C_{e}\left(q_{e}\right)-P^{\prime}(Q) q_{e}=P(Q)-w
$$

Totally differentiating both sides with respect to $w$ and $q_{d}$ and rearranging the following equations, we obtain:

$$
\begin{aligned}
\frac{\partial q_{e}}{\partial w} & =\frac{-1}{M C_{e}^{\prime}\left(q_{e}\right)-2 P^{\prime}(Q)-P^{\prime \prime}(Q) q_{e}}=\frac{1}{\pi_{e}^{\prime \prime}\left(q_{e}\right)}<0 \\
\frac{\partial q_{e}}{\partial q_{d}} & =-\frac{P^{\prime}(Q)+P^{\prime \prime}(Q) q_{e}}{\pi_{e}^{\prime \prime}\left(q_{e}\right)}<0
\end{aligned}
$$

It follows that the best response function $q_{e}\left(q_{d}, w\right)$ is decreasing in $w$ and $q_{d}$ and is uniquely defined. Comparing both equations, we have:

$$
\frac{\partial q_{e}}{\partial q_{d}}=-\left(P^{\prime}(Q)+P^{\prime \prime}(Q) q_{e}\right) \frac{\partial q_{e}}{\partial w} .
$$

The dominant firm can exclude the competitor and set $q_{d}=Q^{m}$ to achieve the monopoly profit $\pi^{m}$. We show now it can earn more than monopoly profits through rent-extraction. Suppose the dominant firm reallocates $q_{e}$ to the entrant while keeping the total output at $Q=Q^{m}$. Substituting the entrant's best response, we can rewrite the dominant firm's profit as:

$$
\hat{\Pi}\left(q_{d}, q_{e}\right)=\pi\left(Q^{m}\right)+\left(c_{d}-M C_{e}\left(q_{e}\right)+P^{\prime}\left(Q^{m}\right) q_{e}\right) q_{e}
$$

Such production reallocation is profitable if and only if:

$$
c_{d}>M C_{e}\left(q_{e}\right)-P^{\prime}\left(Q^{m}\right) q_{e}
$$

Note that the right-hand side is equal to $M C_{e}(0)$ when $q_{e}=0$. The assumption $c_{d}>M C_{e}(0)$ then implies that the above inequality must hold for some $q_{e}>0$. 
We show now that the dominant firm exploits less efficiency rents and earns less profits than facing a competitive fringe firm. Since $q_{e}\left(q_{d}, w\right)$ is monotonic in $w$ and $q_{d}$, choosing $q_{d}$ and $w$ to maximize $\hat{\Pi}\left(q_{d}, w\right)$ is equivalent to maximizing:

$$
\hat{\Pi}\left(q_{d}, q_{e}\right)=\pi(Q)-\left(M C_{e}\left(q_{e}\right)-P^{\prime}(Q) q_{e}-c_{d}\right) q_{e}=\pi(Q)+\hat{R}\left(q_{e}, q_{d}\right),
$$

where $\hat{R}\left(q_{e}, q_{d}\right) \equiv\left(c_{d}-M C_{e}\left(q_{e}\right)+P^{\prime}(Q) q_{e}\right) q_{e}$ denotes the efficiency rents. Given $q_{d}$, Since $\hat{R}\left(q_{e}\right)<R\left(q_{e}\right)=\left(c_{d}-M C_{e}\left(q_{e}\right)\right) q_{e}$ for any $q_{e}$, a simple revelation argument shows that $\hat{q}_{e}=$ $\arg \max \hat{R}(q)<q_{e}^{*}=\arg \max R(q)$. Thus, the dominant firm exploits less efficiency gains than facing the competitive fringe entrant: $\hat{R}\left(\hat{q}_{e}\right)<R\left(q_{e}^{*}\right)$, and also earns less total profit: $\hat{\Pi}^{*}=\pi^{*}\left(Q^{*}\right)+\hat{R}\left(\hat{q}_{e}\right)<\pi^{m}+R\left(q_{e}^{*}\right)$.

It remains to prove the last statement regarding the final price and verify the price squeeze in equilibrium. Recall that the dominant firm's profit is given by:

$$
\hat{\Pi}\left(q_{d}, w\right)=\pi(Q)-\left(P(Q)-w-c_{d}\right) q_{e}\left(q_{d}, w\right) .
$$

Differentiating $\hat{\Pi}\left(q_{d}, w\right)$ with respect to $w$ and $q_{d}$, we obtain:

$$
\begin{aligned}
& \frac{\partial \hat{\Pi}\left(q_{d}, w\right)}{\partial w}=\left[\left(\pi^{\prime}(Q)-P^{\prime}(Q) q_{e}\right)-\left(P(Q)-w-c_{d}\right)\right] \frac{\partial q_{e}\left(q_{d}, w\right)}{\partial w}+q_{e} \\
& \frac{\partial \hat{\Pi}\left(q_{d}, w\right)}{\partial q_{d}}=\left(\pi^{\prime}(Q)-P^{\prime}(Q) q_{e}\right)\left(1+\frac{\partial q_{e}}{\partial q_{d}}\right)-\left(P(Q)-w-c_{d}\right) \frac{\partial q_{e}}{\partial q_{d}}
\end{aligned}
$$

Assume that the interior optimum exists; then the optimal $q_{d}$ and $w$ must satisfy the following first-order conditions:

$$
\begin{aligned}
q_{e} & =-\left[\left(\pi^{\prime}(Q)-P^{\prime}(Q) q_{e}\right)-\left(P(Q)-w-c_{d}\right)\right] \frac{\partial q_{e}\left(q_{d}, w\right)}{\partial w} \\
\pi^{\prime}(Q)-P^{\prime}(Q) q_{e} & =-\left[\left(\pi^{\prime}(Q)-P^{\prime}(Q) q_{e}\right)-\left(P(Q)-w-c_{d}\right)\right] \frac{\partial q_{e}\left(q_{d}, w\right)}{\partial q_{d}}
\end{aligned}
$$

Using the relation (15), we obtain:

$$
\begin{aligned}
\pi^{\prime}(Q)-P^{\prime}(Q) q_{e} & =-\left[\left(\pi^{\prime}(Q)-P^{\prime}(Q) q_{e}\right)-\left(P(Q)-w-c_{d}\right)\right] \frac{\partial q_{e}\left(q_{d}, w\right)}{\partial q_{d}} \\
& =\left[\left(\pi^{\prime}(Q)-P^{\prime}(Q) q_{e}\right)-\left(P(Q)-w-c_{d}\right)\right] \frac{\partial q_{e}}{\partial w}\left(P^{\prime}(Q)+P^{\prime \prime}(Q) q_{e}\right) \\
& =-\left(P^{\prime}(Q)+P^{\prime \prime}(Q) q_{e}\right) q_{e},
\end{aligned}
$$

which amounts to:

$$
\pi^{\prime}(Q)=-P^{\prime \prime}(Q) q_{e}^{2}
$$


Note that the first-order conditions are necessary conditions for the interior optimum. Hence, the above equation is also a necessary condition for the optimal output. That is, the optimal output $Q^{*}$ must satisfy $\pi^{\prime}\left(Q^{*}\right)=-P^{\prime \prime}\left(Q^{*}\right)\left(q_{e}^{*}\right)^{2} \cdot{ }^{30}$ It follows that $\pi^{\prime}(Q) \geq 0$ if and only if $P^{\prime \prime}(Q) \leq 0$. Thus, $Q<Q^{m}$ if the inverse demand function is concave and $Q>Q^{m}$ if the inverse demand function is convex.

Finally, we verify that $P(Q)-w<c_{d}$ at the optimum. To see this, rearranging the FOC (16) and using conditions (18) and (13), we obtain:

$$
\begin{aligned}
P(Q)-w-c_{d} & =\pi^{\prime}(Q)-P^{\prime}(Q) q_{e}+\frac{q_{e}}{\frac{\partial q_{e}\left(q_{d}, w\right)}{\partial w}} \\
& =\pi^{\prime}(Q)-P^{\prime}(Q) q_{e}-\left(M C_{e}^{\prime}\left(q_{e}\right)-2 P^{\prime}(Q)-P^{\prime \prime}(Q) q_{e}\right) q_{e} \\
& =-\left[P^{\prime}(Q)+P^{\prime \prime}(Q) q_{e}+M C_{e}^{\prime}\left(q_{e}\right)-2 P^{\prime}(Q)-P^{\prime \prime}(Q) q_{e}\right] q_{e} \\
& =-\left[M C_{e}^{\prime}\left(q_{e}\right)-P^{\prime}(Q)\right] q_{e}<0
\end{aligned}
$$

it thus follows that $P(Q)-w<c_{d}$ in equilibrium. Q.E.D.

\section{Appendix B: Proof of Proposition 4}

We now examine the impact of banning price squeezes. When price squeezing is not allowed, the dominant firm must choose $w$ and $q_{d}$ such that $P(Q)-w \geq c_{d}$. Suppose the ban is implemented through the input price, in which the dominant firm is obliged to set input price such that $w \leq P(Q)-c_{d}$. The dominant firm chooses $w$ and $q_{d}$ to maximize its profit:

$$
\hat{\Pi}\left(q_{d}, w\right)=\pi(Q)-\left(P(Q)-w-c_{d}\right) q_{e}\left(q_{d}, w\right)
$$

subject to the constraint $w \leq P(Q)-c_{d}$.

First, we show that the constraint $P(Q)-c_{d}-w \geq 0$ must be binding at the optimum. Suppose $P(Q)-c_{d}-w>0$ for optimal $q_{d}$ and $w$. Solving for the first-order condition for $q_{d}$, $\frac{\partial \hat{\Pi}\left(q_{d}, w\right)}{\partial q_{d}}=0$, we obtain:

$$
\pi^{\prime}(Q)-P^{\prime}(Q) q_{e}=\frac{\left(P(Q)-w-c_{d}\right)}{\left(1+\frac{\partial q_{e}}{\partial q_{d}}\right)} \times \frac{\partial q_{e}}{\partial q_{d}}
$$

\footnotetext{
${ }^{30}$ The second-order conditions are quite messy and require complicated assumptions. Since we do not characterize the optimum, we rely on necessary conditions for the comparative statics.
} 
Substituting into the first-order derivative for $w$, we have:

$$
\begin{aligned}
\frac{\partial \hat{\Pi}\left(q_{d}, w\right)}{\partial w} & =\left[\left(\pi^{\prime}(Q)-P^{\prime}(Q) q_{e}\right)-\left(P(Q)-w-c_{d}\right)\right] \frac{\partial q_{e}\left(q_{d}, w\right)}{\partial w}+q_{e} \\
& =\left[-\frac{\left(P(Q)-w-c_{d}\right)}{\left(1+\frac{\partial q_{e}}{\partial q_{d}}\right)}\right] \frac{\partial q_{e}\left(q_{d}, w\right)}{\partial w}+q_{e} .
\end{aligned}
$$

It follows that $\frac{\partial \hat{\Pi}\left(q_{d}, w\right)}{\partial w}>0$ since $\frac{\partial q_{e}\left(q_{d}, w\right)}{\partial w}<0$ and:

$$
1+\frac{\partial q_{e}}{\partial q_{d}}=\frac{M C_{e}^{\prime}\left(q_{e}\right)-P^{\prime}(Q)}{M C_{e}^{\prime}\left(q_{e}\right)-2 P^{\prime}(Q)-P^{\prime \prime}(Q) q_{e}}>0 .
$$

Thus, it is optimal to increase $w$ such that $P(Q)-c_{d}-w=0$, a contradiction.

Second, prohibiting price squeezes reduces the input price and increases the entrant's output. The entrant's best response $q_{e}\left(q_{d}, w\right)$ is given by the FOC: $M C_{e}\left(q_{e}\right)-P^{\prime}(Q) q_{e}=P(Q)-w$. Note that $P(Q)-w=c_{d}$ under prohibition whereas $P(Q)-w<c_{d}$ without prohibition. It is straightforward to check that the left-hand-side $M C_{e}\left(q_{e}\right)-P^{\prime}(Q) q_{e}$ increases in $q_{e}$. Hence, banning price squeezing increases the entrant's output: $\hat{q}_{e}\left(q_{d}, w\right)>q_{e}^{*}\left(q_{d}, w\right)$. This also implies a lower input price with prohibition: $\hat{w}<w^{*}$ since $q_{e}\left(q_{d}, w\right)$ decreases in $w$.

Third, prohibiting price squeezes increases total output and reduces the final price. Recall that the optimal output with prohibition $\hat{Q}$ is given by FOC $(19): \pi^{\prime}(\hat{Q})=P^{\prime}(\hat{Q}) \hat{q}_{e}$, whereas the equilibrium output without prohibition $Q^{*}$ satisfies $\pi^{\prime}\left(Q^{*}\right)=-P^{\prime \prime}\left(Q^{*}\right)\left(q_{e}^{*}\right)^{2}$. If $P^{\prime \prime}(Q)<0$, then $\hat{Q}>Q^{m}>Q^{*}$. Suppose $P^{\prime \prime}(Q)>0$. Then $P^{\prime}(Q)+P^{\prime \prime}(Q) q_{e}<P^{\prime}(Q)+P^{\prime \prime}(Q) Q<0$ implies:

$$
\pi^{\prime}\left(Q^{*}\right)=-P^{\prime \prime}\left(Q^{*}\right)\left(q_{e}^{*}\right)^{2}>P^{\prime}\left(Q^{*}\right) q_{e}^{*}
$$

Denoting by:

$$
\Psi(Q)=\pi^{\prime}(Q)-P^{\prime}(Q) q_{e}
$$

then $\Psi(\hat{Q})=0$ but $\Psi\left(Q^{*}\right)>0$. We show $\Psi^{\prime}(Q)<0$, which implies $Q^{*}<\hat{Q}$. Note that:

$$
\begin{aligned}
\Psi^{\prime}(Q) & =\pi^{\prime \prime}(Q)-P^{\prime \prime}(Q) q_{e}-P^{\prime}(Q) \frac{\partial q_{e}}{\partial Q} \\
& =P^{\prime}(\hat{Q})+P^{\prime \prime}(\hat{Q})\left(Q-q_{e}\right)+P^{\prime}(\hat{Q})\left(1-\frac{1}{\partial Q / \partial q_{e}}\right) \\
& =P^{\prime}(\hat{Q})+P^{\prime \prime}(\hat{Q})\left(Q-q_{e}\right)+P^{\prime}(\hat{Q})\left(\frac{1}{1+\frac{\partial q_{e}}{\partial q_{d}}}\right) .
\end{aligned}
$$

It follows that $\Psi^{\prime}(Q)<0$ since $P^{\prime}(\hat{Q})+P^{\prime \prime}(\hat{Q})\left(Q-q_{e}\right)<P^{\prime}(\hat{Q})+P^{\prime \prime}(\hat{Q}) Q<0$ and $1+\frac{\partial q_{e}}{\partial q_{d}}>0$. 
Finally, the binding constraint $w=P(Q)-c_{d}$ also implies:

$$
\frac{\partial \hat{\Pi}\left(q_{d}, w\right)}{\partial q_{d}}=\left(\pi^{\prime}(Q)-P^{\prime}(Q) q_{e}\right)\left(1+\frac{\partial q_{e}}{\partial q_{d}}\right)
$$

and the optimal quantity $q_{d}$ must satisfy:

$$
\pi^{\prime}(\hat{Q})=P^{\prime}(\hat{Q}) \hat{q}_{e}
$$

Since $\pi^{\prime}(\hat{Q})<0$, the equilibrium output $\hat{Q}$ exceeds the monopoly level $Q^{m}$. 


\section{References}

Aghion, Philippe. and Patrick Bolton (1987), "Contracts as a Barrier to Entry', American Economic Review, 77 (3): 388-401.

Allain, Marie-Laure, Claire Chambolle and Patrick Rey (2015), "Vertical Integration as a Source of Hold-Up", Review of Economic Studies, 83(1): 1-25.

Bork, Robert, (1978). The Antitrust Paradox: A Policy at War with Itself, New York: Basic Books.

Calzolari, Giocoma and Vincenzo Denicolo (2021), "Exploiting Rivals' Strengths", working paper.

Carlton, Dennis (2008), "Should 'Price Squeeze' be a Recognized Form of Anticompetitive Conduct?" Journal of Competition Law and Economics, 4(2): 271-278.

Chen, Yongmin (2001), "On Vertical Mergers and Their Competitive Effects", Rand Journal of Economics, 32(4): 667-685.

Chen, Zhijun (2020), "Vertical Integration and Rent-Extraction: Lessons from the Dairy Industry", working paper.

Chen, Zhijun, Bruno Jullien, and Patrick Rey (2017), "Margin Squeeze", working paper.

Chen, Zhijun and Patrick Rey (2012), "Loss Leading as an Exploitative Practice", American Economic Review, 102 (7): 3462-3482.

Gaudin, Germain and Despoina Mantzari (2016), "Margin Squeeze: An Above-Cost Predatory Pricing Approach", Journal of Competition Law and Economics, 12 (1): 151-179.

Hart, Oliver and Jean Tirole (1990), "Vertical Integration and Market Foreclosure", Brookings Papers on Economic Activity, 1: 205-276.

Hay, George and Kathryn McMahon (2012), "The Diverging Approach to Price Squeezes in the United States and Europe". Journal of Competition Law and Economics, 8(2): 259-296.

Jullien, Bruno, Patrick Rey, and Claudia Saavedra (2014), "The Economics of Margin Squeeze", IDEI report.

Ordover, Janusz A., Garth Saloner and Steven C. Salop (1990), "Equilibrium Vertical Foreclosure," American Economic Review, 80(1):127-142.

Posner, Richard (1976). Antitrust Law: An Economic Perspective. University of Chicago Press.

Rey, Patrick and Jean Tirole (2007), "A Prime on Foreclosure", Handbook of Industrial Organization, Vol. III. North Holland, 2145-2220. 
Riordan, Michael (1998), "Anticompetitive Vertical Integration by a Dominant Firm", American Economic Review, 88(5): 1232-1248.

Salinger, Michael A. (1988), "Vertical Mergers and Market Foreclosure," Quarterly Journal of Economics, 103(2):345-356.

Salop, Steven and David Scheffman (1987), "Cost-Raising Strategies," Journal of Industrial Economics, 36(1): 19-34.

Sidak, Gregory (2008), "Abolishing the Price Squeeze as a Theory of Antitrust Liability", Journal of Competition Law and Economics, 4(2): 279-309.

Vickers, John (2010), "Competition Policy and Property Rights", Economic Journal, 120: 375-392.

Wiethaus, Lars and Rainer Nitsche (2014), "Margin Squeeze: An Overview of EU and National Case Law", e-Competition: Antitrust Case Laws e-Bulletin, No. 46442. 